\title{
Analysis of Practical Assessment Sheet Needs in Beauty Education Programs in State University
}

\author{
Trisnani Widowati ${ }^{1}$, Widya Puji Astuti ${ }^{1}$, Ade Novi Nurul Ihsani ${ }^{3}$, Wulansari Prasetyaningtyas ${ }^{4}$, \\ Lydia Katarina ${ }^{5}$, and Anggie Cristanti ${ }^{6}$ \\ ${ }^{1}$ PKK, Fakultas Teknik, Universitas Negeri Semarang, Semarang, Indonesia
}

\begin{abstract}
Keywords: The analysis of the needs, practice assessment sheet.
Abstract: Learning activities cannot be separated from assessment. To ensure the achievement of student competencies in carrying out practice, lecturers need to provide an assessment. Accordingly, lecturers need to use practice assessment sheet. This study aims to describe the analysis of practicum assessment sheet needs on beauty education programs at State Universities. Data obtained from questionnaires and interviews. The results obtained from the analysis of the needs of the questionnaire results submitted to lecturers supporting study programs on beauty education programs in 4 institutions showed that $80 \%$ out of the 4 tertiary institutions had used practice assessment sheets. But, the supporting facilities to develop the assessment sheet are still in small amounts (33.33\%). The practice assessment sheet used so far has been tested for validity based on $13.33 \%$ field study groups. Seeing the results of the analysis of the lecturers' needs, there is a need for socialization and supporting facilities for the development of practice assessment sheets accompanied by theoretical and practical assessment rubrics so that, it can be used by lecturers in the Department of Makeup Education in State Universities.
\end{abstract}

\section{INTRODUCTION}

Assessment is an important part of learning activities which cannot be separated. Assessment is used as a reference to see the level of success of student competencies in implementing practices and the effectiveness of lecturers in learning. If there is an error in the assessment process, there will be misinformation about the quality of the teaching and learning process and in the end the true educational objectives will not be achieved. Therefore, the assessment must be carried out in accordance

Peraturan Menteri Pendidikan Nasional Republik Indonesia Nomor 20 Tahun 2007 tentang Standar Penilaian Pendidikan. Good assessment will provide useful information for improving the quality of teaching and learning process.

Needs analysis is a tool to identify problems in order to determine appropriate actions (Morrison, 2001: 27). Needs analysis is a tool or method for identifying problems to determine the right action or solution.

There are four stages in conducting a needs analysis namely (Abidin, 2007: 62):
1. Planning : what needs to be done is ; make lecturers clarification, who will be involved in the activities and how to unite them

2. Data accumulation : need to consider the size of the sample in its distribution

3. Data analysis : after the data is collected then the data is analyzed with consideration: needs.

4. Final report : in a needs analysis report include four parts, objective analysis, process analysis, results analysis with tables and brief description, recommendations related to the data.

The Beauty Education Program is one of the educational institutions that aims to prepare prospective undergraduate in the field of beauty education programs and also produce workers who perform according to the needs of the industrial world. State Universities that have beauty study education programs are Jakarta State University, Medan State University, Padang State University, Surabaya State University, and Semarang State University. Basically, almost all subjects in the Curriculum of Beauty Education Program are almost the same. The difference only the name of the term in each course name. 
The learning process in the class of Beauty Education Program put more emphasis on mastering competency skills, where evidence of learning outcomes can be assessed through process and results. The assessment process according to PP No. $19 / 2005$, conducted through observing changes in behaviour and attitudes to assess the development of student competencies.

Process assessment, in the form of observations when doing lecture and doing practices. Evaluation of results, in the form of the achievement value of mastery of student competencies. Each course covers the whole domain of competence both cognitive, affective, and psychomotor. In connection with the three domains of competence, the assessment of learning outcomes is one of the important learning components and need to get the attention of lecturers. Assessment is an activity that cannot be separated by the learning process, even it is vital in the education and teaching system in formal education institutions (A. Manap, 2009).

Based on the opinion of Basuki and Hariyanto (2014: 6), assessment is a series of activities to obtain, analyze, and interpret data about the processes and learning outcomes of students conducted systematically and continuously. Assessment is the interpretation of measurement results and determination of learning achievement outcomes (Iriyanti, 2004: 3).

Pre-practice, practice and post-practice assessments have different characteristics in the process of assessing practice results. By using prepractice, practice and post-practice assessments, lecturers can find out students' competencies in practicing.

Widya (2015: 20), assessment is information in decision making based on the collection of evidence, measurement results, analyzing results about the process and learning outcomes achieved by individuals in determining the achievement of learning outcomes. In this case, whether the learning process and results achieved by students are in accordance with the stated learning objectives.

When evaluating, there is a possibility that the lecturer has not used the assessment sheet which is equipped with rubrics. Yulmiati research results (2014: 31), that the experience of teachers in developing assessment instruments is still minim. According to one of the Department of Beauty Education Program in State Universities, based on the results of an interview on March 4, 2015 that to make an assessment sheet that is equipped with rubrics and scoring techniques, requires no small cost. The assessment sheet must be detailed and in accordance with the components to be assessed, so that the assessment sheet can be used to assess the results of the achievement of mastery of student competencies. Widya's research results (2015: 1213), the results of the assessment using instruments were able to comprehensively inform the performance of students while carrying out practical learning. With assessment instruments can prevent speculative actions from lecturers in conducting assessments to determine the final grade after doing practice.

Through this research, we want to prove that there is a possibility that the Beauty Education Program in State Universities has not used the practice assessment sheet. Hopes of the results of this study can provide input to the Study Program on Beauty Education Program in State Universities. Moreover, with the existence of the Asosiasi Perkumpulan Program Studi Tata Rias Indonesia (PPTRI), which can be a forum for equalizing concepts in making practice assessment sheets for students.

\section{METHOD}

This study is an early stage research which is included in the pre-development stage in the research and development ( $R$ \& $\mathrm{D})$ procedure (Sugiyono, 2010). In this study, a needs analysis of the practice assessment sheet is done by gathering the information needed through questionnaires and interviews. This research was conducted with a descriptive research approach, is an activities that is conducted to uncover information, facts, or phenomena in the field and describe such information or facts as they are. This research takes place in the Beauty Education Program at State Universities. Each study program has different characteristics according to the environment and condition of the study program.

The research data were obtained using a questionnaire and interviews with beauty education program lecturer's at state universities about the use of practice assessment sheets. The results of the study are reported in the form of descriptive statistics, by displaying statistical data and an explanation of these data.

\section{RESULTS AND DISCUSSION}

Based on the results of interviews with beauty education program lecturers at state universities, it was concluded that most of the lecturers had used practice assessment sheets, but the practice 
assessment sheets that are equipped with rubrics. The practice assessment sheet that has been used so far, only a few have passed the validity test because the supporting facilities to make the practice assessment sheet are still minimal. Therefore, they still need socialization and supporting facilities to develop practice assessment sheets.

\section{REFERENCES}

Abidin, Z. (2007). Analisis Kebutuhan Pembelajaran dan Analisis Pembelajaran dalam Desain Sistem Pembelajaran. Artikel Universitas Muhammadiyah Surakarta, 19 (1).

Astuti, W.P. (2015). Pengembangan Instrumen Penilaian Unjuk Kerja Praktik Perawatan Kulit Wajah Berbasis Kompetensi di Universitas Negeri Semarang. Innovative Journal of Curriculum and Educational Technology, 4 (1).

(2015). Pengembangan Instrumen Penilaian Unjuk Kerja Praktik Perawatan Kulit Wajah Berbasis Kompetensi di Universitas Negeri Semarang. Tesis. Unnes. Semarang.

Manap. A. (2009). Implementasi Penilaian Pembelajaran pada SMK Jurusan Bangunan di Daerah Istimewa Yogyakarta. Jurnal Pendidikan Teknologi dan Kejuruan UNY.

Badan Standar Nasional Pendidikan. (2007). Panduan Penilaian Kelompok Mata Pelajaran Estetika. Badan Standar Nasional Pendidikan (BSNP), Jakarta: Departemen Pendidikan Nasional.

Iriyanti, P. (2004). Penulisan Modul Paket Pembinaan Penataran "Penilaian Unjuk Kerja". Yogyakarta. Departemen Pendidikan Nasional Direktorat Jenderal Pendidikan Dasar dan Menengah Pusat Pengembangan Penataran Guru Matematika.

Peraturan Menteri Pendidikan Nasional Republik Indonesia Nomor 19 Tahun 2005 tentang Standar Nasional Pendidikan.

Peraturan Menteri Pendidikan Nasional Republik Indonesia Nomor 20 Tahun 2007 tentang Standar Penilaian Pendidikan.

Sugiyono. (2010). Metode Penelitian Pendidikan Pendekatan Kuantitaif. Bandung. Alfabeta.

Yulmiati. (2014). Analisis Kebutuhan Terhadap Pengembangan Instrumen Penilaian Otentik. Jurnal Pelangi, 7(1). ertiary level is regulated by each institution in accordance with the applicable laws and regulations. From the results of the needs analysis, this data also helps researchers to obtain consideration in developing practical and theoretical assessment sheets based on the subject.

\section{CONCLUSION}

Based on the research results obtained, the analysis of the need for the use of practice assessment sheets shows that so far the lecturers have not used the 